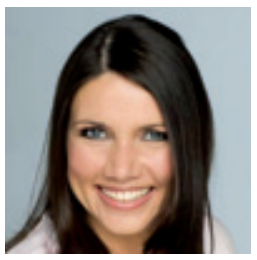

\title{
Just say no!
}

\section{En resept er en håndfast bekreftelse} på at vi ikke fungerer helt akkurat nå, men er kanskje ikke det som skal til for å få oss på bena.

Jeg skulle gå til toppen av Kilimanjaro. Tro meg når jeg sier at dette er svært ukarakteristisk for meg. Av legning er jeg svært bedagelig anlagt, og min erfaring med høye fjell og dype daler er observasjon på trygg avstand. Seks meter fra flatskjermen burde holde. Natur gjør seg etter min mening best på Discovery Channel.

Jeg oppdaget at det kreves et godt utfylt vaksinasjonskort om man skal nå Uhuru Peak på Afrikas høyeste fjell, med kryss for hepatitt A, hepatitt B, difteri, stivkrampe, kikhoste, polio og gulfebersertifikat. Legg til malariatabletter, blodfortynnende og høydemedisin, og topp dette med kulltabletter, hodepinetabletter, salttabletter, Zyrtec og Pez. OK, kanskje ikke det siste. Hva i all verden skjedde med mot i brystet og gode tursko?

Mellom meg og mine venner i den hardt prøvede legemiddelindustrien står legen. Det hadde jo aldri vært noe problem tidligere, men denne gangen skulle det dessverre vise seg at turoperatørens liste over reseptbelagte medisiner de mente jeg trengte, ikke korresponderte med antall resepter legen min var villig til å skrive ut. En lege som ikke virker, tenkte jeg.

Han gikk kritisk gjennom hver anbefaling, og spurte hvorfor jeg trengte Albyl E (kjekt å ha) og Diamox (hørt at de gir en kriblende virkning). Uten gode svar fra meg utover at «det står på listen», plukket han opp telefonen og konfererte med en ekspert som snakket så høyt at jeg kunne høre hans nasale stemme gjennom telefonen: «Kilimanjaro, sier du? Det er jo en riiimelig lang bakke da.»

Tre vaksiner og en halv besvimelse senere sto jeg med vesken full av moderne avlatsbrev. Eksperten hadde talt og legen motvillig adlydt. Hvis kroppen er et tempel, sørger det norske helsevesenet for relativt billige resepter for å bøte på livsstilssynder, hypokondri og - som nå - en smørbrødliste av medikamenter som kanskje kunne komme til nytte dersom atte, hvis om atte.

På ett punkt satte legen imidlertid foten ned. Da jeg med store, fuktige øyne la ut om flyskrekk og en planlagt reise til Cuba og dristet meg til å foreslå en liten dose Valium på veien, var svaret et bestemt nei. Jeg fikk gjøre som alle andre og ta meg et glass rødvin, mente han. Ironisk nok er fly det eneste stedet jeg aldri drikker.

Legens åpenbare misbilligelse mot listen av reseptbelagte medisiner hadde en uventet bivirkning. Selv nå - noen år etter at jeg trosset både min egen natur og naturen selv ved å karre meg opp til toppen av Kilimanjaro - husker jeg hans befalinger for en trygg reise. Han innledende uvillighet til bare å skrive ut resepter for et godt ord innga respekt. Ikke bare for ham, men også for medikamentene i seg selv. Vaksiner må man ha, og malariatabletter. Utover det fikk det meste ligge i fred og ble avhendet umiddelbart etter turen.

Jeg fikk fornyet respekt for legestanden, som jeg tidligere hadde opplevd å få sykmeldinger av uten at de leet på øyelokket og som sjelden eller aldri foreslo alternativer. Som pasienter oppsøker vi lege vel så mye for veiledning, som for akutt hjelp. Spesielt nå som vi er tastetrykk unna å diagnostisere oss selv med kreft en dag vi føler oss litt pjusk, og møter opp med forslag til medisiner vi tror passer for oss når vi kommer inn på legekontoret. Selv barn i en godtebutikk vet utmerket godt at de ikke kan få alt de peker på, men vil forsøke seg. I forholdet mellom lege og pasient må legen være den voksne og si nei. Det er ikke sikkert vi en gang vil ha det vi ber om, men vi ber om det vi vet vi kan få. En resept er en håndfast bekreftelse på at vi ikke fungerer helt akkurat nå, men kanskje det som skal til for å få oss på bena, ikke best formuleres på latin.

Legg Hippokrates til side og bruk Sokrates' metode - still kompetente spørsmål om hva og hvorfor. Som pasienter vet vi ofte hva som egentlig er best for oss, men søker gjerne en bekreftelse på at enkleste utvei er helt greit.

For å realisere oss selv som mennesker enten det er å bestige Kilimanjaro eller fungere $\mathrm{i}$ arbeidslivet - så vil det til syvende og sist tross alt være egen evne og vilje det kommer an på, ikke antall resepter vi klarer å tigge til oss hos legen.

Noen ganger er det helt ok å si nei.

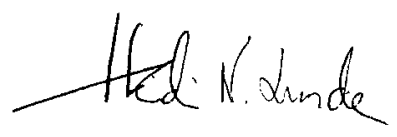

\section{I neste nummer:}

Infantilt hemangiom

Sykefravær

Solarier og D-vitamin
Legers produktivitet

Skaderegister

Immunrespons uten infeksjon 